\title{
Diversity of Penicillium in soil of Caatinga and Atlantic Forest areas of Pernambuco, Brazil: an ecological approach
}

\section{Roberta Cruz ${ }^{1}$, Cledir Santos ${ }^{2,3}$, Juliana Silva de Lima ${ }^{1}, K_{\text {Keila Aparecida }}$ Moreira $^{4}$ and Cristina Maria de Souza-Motta ${ }^{1^{*}}$}

${ }^{1}$ Department of Mycology, Federal University of Pernambuco, 50670-420, Recife, Pernambuco, Brazil.

2 IBB-Institute for Biotechnology and Bioengineering, Centre of Biological Engineering, Micoteca da Universidade do Minho, Campus of Gualtar, Braga, Portugal.

${ }^{3}$ Cereal Research Centre, Agriculture and Agrifood Canada, 195 Dafoe Road, Winnipeg MB, Canada R3T 2M9

${ }^{4}$ Academic Unit of Garanhuns, Federal Rural University of Pernambuco, Garanhuns, Pernambuco, 5292-270, Brazil.

With 5 figures and 1 table

\begin{abstract}
Caatinga is characterised as being a unique semi-arid biome only found in Brazil. It is characterised mainly for its soil poor in mineral and organic nutrients, and low water activity. On the other hand, Atlantic Forest is mainly characterised by its nutrient-rich soil, and its high water activity. Fungi are important constituents of both biomes. Among the fungi frequently isolated from soil of both Caatinga and Atlantic Forest, species of Penicillium are prominent. The richness, abundance, evenness, and dominance of species of Penicillium in soils of the Caatinga and Atlantic Forest areas in Pernambuco, Brazil, were analyzed. The influence of seasonality (rainy and dry seasons) on the communities of species of Penicillium in each biome and their distribution was assessed. A total of 815 Penicillium isolates was found. From this total amount, 370 isolates were found in the Caatinga soil, whereas 445 were found in the Atlantic Forest soil. Thirty-one species were morphologically identified, with 23 of them in the Caatinga soil and 17 in the Atlantic Forest soil. In addition, three isolates from Caatinga soil were only identified to genus. The present study revealed that soils from Caatinga and Atlantic Forest have a high diversity of species of Penicillium, with the Caatinga presenting rare species. Furthermore, the communities of Penicillium species are very different, but well distributed in each biome. In the dry season, there was greater species richness in areas of the two biomes, indicating that the species may be well adapted to low soil water availability for the development and maintenance of balanced communities.
\end{abstract}

Key words: fungal ecology, clima, Penicillium adametzii, Penicillium lanosum, soil fungi.

*Corresponding author: smotta@ufpe.br 


\section{Introduction}

According to Hawksworth (1991) the magnitude of fungal diversity on Earth was estimated to be about 1,5 million species. This estimate was based on extrapolations from several independent data sets, namely: the numbers of fungi vs native plants growing in a particular region on a cross-section of native plants in Great Britain and Ireland, and the numbers of species discovered in a particular alpine community. On the other hand, according to O'Brien et al. (2005) the magnitude of fungal diversity on Earth was estimated ranging from 3,5 to 5,1 million species. In this case authors have evaluated soil fungal diversity at two sites in a temperate forest (Duck Forest, Durham, NC, USA). For these estimations authors used direct isolation of small-subunit and internal transcribed spacer (ITS) rRNA genes by PCR and high-throughput sequencing of cloned fragments.

Taking into consideration the estimates by the Convention on Biological Diversity (CBD), Brazil is home to between 15 and $20 \%$ of all global biodiversity. It is the country with the largest number of endemic species and its biodiversity can be a source of important biologically active compounds. Moreover, a huge diversity of fungi, with many rare or even unknown species is expected to be hosted in Brazil (Barreiro \& Bolzani, 2009; Lewinsonhn \& Prado, 2002). Fungi inhabiting soils of the Brazilian Atlantic Forest and semi-arid regions vegetation, such as Caatinga, can particularly be of biotechnological interest.

Caatinga covers approximately $800,000 \mathrm{~km}^{2}$ that is c. $10 \%$ of the Brazilian national territory and it is reported to be only exclusively endemic biome from the Brazilian semi-arid regions (Rodal et al., 2008). The soil in this area is characterised by $0.7-$ $1.1 \%$ organic matter and $\mathrm{pH}$ 5.4. Climate is semi-arid hot with a dry summer, high daytime temperatures (c. 30 to $40^{\circ} \mathrm{C}$ ) and lower nighttime temperatures $\left(\right.$ c. $15^{\circ} \mathrm{C}$ ). Furthermore, the mean annual precipitation is $610 \mathrm{~mm}$ (Goto et. al., 2009). In this semi-arid area, Caatinga vegetation is mainly represented by species of Euphorbiaceae, Caesalpiniaceae, Malpighiaceae, Myrtaceae, Mimosaceae, Fabaceae, and Cactaceae (e.g. Cnidoscolus obtusifolius Pohl, Caesalpinia microphylla Mart., Byrsonima gardneriana A. Juss., Eugenia biflora (L.) Dc., Acacia bahiensis Benth., Bocoa mollis (Benth) Cowa, and Pilosocereus tuberculatus (Werdermann) Byles \& Rowley), among others. This important biological heritage cannot be found anywhere else on the planet (Kennedy \& Smith, 1995).

In contrast, Brazilian Atlantic Forest is mainly characterised by highly humid environment with coastal plant formation. It is considered the rarest ecosystem in Brazil and covers about 98,800 $\mathrm{km}^{2}$ of extension (Morellato, 2000) that is c. $1.3 \%$ of the Brazilian national territory. Currently, it represents approximately $9 \%$ of its original area (Durigan et al., 2000). This area comprises three types of forests: Ombrophilous Dense forests, Semideciduous and Deciduous Stationary forests from the South and Southern regions, and Ombrophylus Mist forest, also known as Araucaria forest from Southern Brazil (Colombo \& Joly, 2010). Although it suffers from conservation deficit, this biome is one of the 25 hotspot with the greatest biodiversity in the world (Myers et al., 2000; Tabarelli et al., 2005). 
Among fungi commonly isolated from soil, species belonging to genus Penicillium are notable. Most of them are saprotrophic with few nutritional requirements. In addition, the genus Penicillium is extremely important in nature because some of its c. 300 species are highly active in the recycling of organic matter (Kirk et al., 2008; Pitt, 1991; Samson \& Frisvad, 2004). Some of them are also producers of antibiotics (Harris et al., 2009), organic acids, and enzymes with industrial interest (Soccol et al., 2006).

Studies on the fungal communities of saprotrophic Penicillia as a genus present in the soil of Brazilian Atlantic Forest and Caatinga are scarce. It is, however, important to determine not only the individual fungal members and their functions, but also the effects of disturbance or environmental stress on these communities. This last parameter can be measured by several numerical indices. The aim of this study was to determine the richness, abundance, evenness, dominance and frequency of species of Penicillium in soils of Atlantic Forest and Caatinga in the State of Pernambuco, Brazil, as well as the influence of seasonality (rainy or dry) in each biome on the communities of these species.

\section{Materials and methods}

AREA OF STUDY, RAINFALL AND SAMPLE COLLECTION: Six sample collections were conducted in soil of both Caatinga vegetation and Brazilian Atlantic Forest regions. In the area of Caatinga, sample collections were performed at the Catimbau National Park at the City of Buíque, State of Pernambuco, Brazil (S $08^{\circ} 04^{\prime} 25^{\prime \prime}$ and $\left.\mathrm{W} 37^{\circ} 15^{\prime} 52^{\prime \prime}\right)$. In this case, three sample collections were conducted in the dry months of June, July and August 2009, when rainfall was 0.0, 11.0 and $0.0 \mathrm{~mm}$, respectively. The sample collections during the rainy season were performed in February, March and April 2010, when rainfall was 109.0, 120.0 and $236.0 \mathrm{~mm}$, respectively. On the other hand, sample collections in the Brazilian Atlantic Forest were performed at the Park of Dois Irmãos. This park is maintained by the State of Pernambuco and is located at the north-western City of Recife (S 8 $8^{\circ} 15^{\prime} 30^{\prime \prime}$ and W 35 $\left.57^{\prime} 00^{\prime \prime}\right)$. In this last case, sample collections during the rainy season were conducted in June, July and August 2009, which had rainfall of 115.0, 117.7 and $115.0 \mathrm{~mm}$, respectively. In the dry period, collections were made in February, March and April 2010, with rainfall of 0.0, 0.0 and 11.3, mm, respectively. Samples collected in both cases were maintained at room temperature while being transported into sterilised thin polyethylene plastic bags to the research laboratory of URM culture collection.

In both case, soil samples were collected in three transects of $4 \times 25 \mathrm{~m}$ at a depth of 00-20 cm. A total of ten samples from each transect were combined to give a single composed sample. According to the number of transects established in this study 36 samples were obtained.

ISOLATION AND PURIFICATION: Isolation of fungi was performed by suspension methods according to Clark (1965). All of the 36 composed soil samples were suspended in sterile distilled water and successive dilutions were performed. Composed soil aqueous suspensions at a concentration 1:10000 $\mathrm{g} \cdot \mathrm{mL}^{-1}$ were obtained. Each aqueous suspension sample of composed soil was inoculated in 5 different Petri dishes containing Sabouraud agar supplemented with $50 \mathrm{mg} \cdot \mathrm{L}^{-1}$ chloranphenicol (SA-C), and dichloran agar with rose bengal supplemented with $50 \mathrm{mg} \cdot \mathrm{L}^{-1}$ chloranphenicol (DARB-C). Overall, 180 Petri dishes for Caatinga soil and 180 Petri dishes for Brazilian Atlantic Forest soil were obtained. The plates were kept at $28^{\circ} \mathrm{C}\left( \pm 2^{\circ} \mathrm{C}\right)$ for $72 \mathrm{~h}$.

In order to purify fungal isolates, fragments of fungal colonies were transferred to Petri dishes containing SA-C medium. After confirmation of purity the fungal cultures were maintained on malt extract agar (MEA) at $25^{\circ} \mathrm{C}\left( \pm 2^{\circ} \mathrm{C}\right)$.

IDENTIFICATION OF SPECIES: The methodology used for identification was described by Pitt (1991). Spores of Penicillium isolates were suspended in $1.0 \mathrm{~mL}$ of an aqueous solution containing $0.2 \%$ agar and $0.05 \%$ Tween 80. Petri dishes containing $25 \mathrm{~mL}$ Czapek Yeast Agar (CYA), MEA and 25\% 
Glycerol Agar medium (G25N) were inoculated in triplicate with $2 \mu \mathrm{L}$ of the suspension containing Penicillium spores described above. Petri dishes were incubated at $5^{\circ} \mathrm{C}, 25^{\circ} \mathrm{C}$ and $37^{\circ} \mathrm{C}$ for $\mathrm{CYA}$ and at $25^{\circ} \mathrm{C}$ for MEA and G25N. Macro- and microscopic traits were observed to identify each species. Identification followed the taxonomic keys and guides available for Penicillium species (Kozakiewicz, 1989; Pitt, 1991; Samson and Frisvad, 2004). The microscopic traits of each species were recorded in photographs using light microscopy (Carl Zeiss Axiostar Plus) and scanning microscopy (SNOM alpha300 S/Witec) at the Centre for Strategic Technology in the Northeast (CETENE, Recife, Brazil). After morphological identification, one isolate of each species was preserved under mineral oil, freeze-drying ampoules and frozen at $-80^{\circ} \mathrm{C}$. Finally, all of the isolates were added to the Catalogue of Micoteca URM Culture Collection (WDCM604).

Statistical analysis: Statistical analysis of the diversity of species of Penicillium on both biomes was performed using the Shannon's index. The abundance was calculated according to Magurran (1988) and equitability was quantified by the evenness index (Pinto-Coelho, 2002). Relative dominance was given by the equation $\mathrm{DA}=\mathrm{NA} / \mathrm{NA}+\mathrm{NB}+\mathrm{NC} \ldots \mathrm{NN} \times 100$, where DA means dominance of the species, and $\mathrm{NA}+\mathrm{NB}+\mathrm{NC} \ldots \mathrm{NN}$ means number of individuals of species A, B, C... N. Species are considered to be dominant species if its presence percentages are above 50\% (Magurran, 1988). Frequency of species during the rainy and dry seasons was calculated by the equation FA $=\mathrm{PA} / \mathrm{P}$ $\times 100$, where $\mathrm{F}$ means frequency of species A; PA means number of samples in which species A is present and $\mathrm{P}$ means the total number of samples. According to Magurran (1988), $\mathrm{F} \geq 50 \%=$ constant species $; 10 \%<\mathrm{F} \leq 49 \%=$ common species and $\mathrm{F} \leq 10 \%=$ rare species

The similarity-dissimilarity of Penicillium species from soil samples of both biomes between rainy and dry seasons was tested based on the Bray-Curtis distance. In this case, it ranged from 0 (similarity) to 1 (dissimilarity) using the matrix density of species (Pinto-Coelho, 2002). The analysis was carried out between collections and transects. The connection method used for the statistical grouping was proportional to the weighted average (WPGMA - Weight Pair Group Mathematical Average) (Rohlf and Fisher, 1968). These calculations were performed using the Software Numerical Taxonomy and Multivariate Analysis System (NTSYS, Exeter - USA).

\section{Results}

In this study a total of 815 isolates belonging to genus Penicillium were obtained. From this total amount, 370 isolates from Caatinga soil and 445 samples from Atlantic Forest soil were obtained. Thirty-one species were morphologically identified. Some of these species where common to both biomes studied. However, 23 of them were found occurring only in the Caatinga soil and 17 of them occurring only in the Atlantic Forest soil. In addition, 3 isolates from Caatinga soil were only identified at genus level. These 3 isolates presented differences between their microscopic features (ornamentation of the wall of the conidia) and those features described in the literature (Raper and Thom, 1949; Pitt, 1991; Samson and Frisvad, 2004). However, as described above in the present work, the fungal identification was achieved using both light microscopy and scanning microscopy. Most descriptions of Penicillia in the literature did not include scanning electron microscopy.

Soil samples from Atlantic Forest yielded a greater number of isolates. In contrast, soil samples from Caatinga presented a greater species richness. Comparing the species richness during the rainy and dry seasons of the two biomes studied, the dry period had the greater number of species (Table 1). Regarding the similarity of species of Penicillium from different soil samples and periods of biomes, the phenetic analysis obtained from the index of Bray and Curtis generated a value $>0.8$. This value indicates a well-adjusted statistical data, which is shown in Figs 1 and 2. In this statistical analysis, the occurrence of 
two major groups of species of Penicillium in both soil biomes is observed. Furthermore, there were no differences between transects in any area examined (Fig. 1). For the first three samplings (sampling 1, 2 and 3, Fig. 1) performed during the dry season in both Caatinga and Atlantic Forest biomes, a well-defined group of species was observed. In addition, for the last three samplings (sampling 4, 5 and 6, Fig. 1) performed during the rainy season, another well-defined group of species was obtained. Species found in this last group were very different from those found in the dry season (Fig. 2).

According to the frequency rate of Penicillium species in the Caatinga soil during the rainy season, 10 species were classified as constant with a frequency $\geq 50 \%$. Furthermore, 6 species were common with a frequency $>10 \% \leq 49 \%$. On the other hand, during the dry season 21 species of Penicillium were found constant and 3 species were common (Fig. 3). Samples collected from the Atlantic Forest soil during the rainy season presented 11 constant species, where 4 of them were common. In this biome, during the dry period 17 species were classified as constant. Comparing the frequency rates of those Penicillium species that occurred in both rainy and dry periods in the Caatinga soil, it was observed that most species were constant in both seasons. Exceptions were found for $P$. aurantiogriseum, which was constant during the rainy season but common in the dry season, and $P$. citreonigrum, $P$. pinophilum and $P$. spinulosum, which were common during the rainy season and constant in the dry season. For the Atlantic Forest soil it was also observed that only $P$. canescens, $P$. brevicompactum and $P$. sclerotiorum were common during the rainy season and constant in the dry season (Fig. 4).

The analysis of species diversity according to the Shannon's index showed results greater than 3.0 bits.ind $^{-1}$. This value indicates high species diversity in both biomes (Fig. 5). Moreover, according to the Pielou's index, the fungal evenness found in this study was greater than 0.5 in both biomes. This value indicates that the fungal species are well distributed in the areas studied. According to the rate of Magurran (1988), in the present study, the most abundant Penicillium species in Caatinga soil were $P$. aurantiogriseum, $P$. citrinum, $P$. glabrum, $P$. implicatum, $P$. janczewskii, $P$. lividum, $P$. oxalicum, $P$. pinophilum, $P$. simplicissimum and $P$. waksmanii. In contrast, the most abundant fungal species in Atlantic Forest soil were P. fellutanum, P. glabrum, P. griseofulvum and P. janthinellum (Table 1).

According to the relative dominance during the rainy season, the dominant species in the Caatinga soil were Penicillium aurantiogriseum (18\%), P. glabrum (17\%), P. lividum (13\%), P. waksmanii (11\%) and P. implicatum (9\%). In contrast, in the dry season the dominant species in the Caatinga soil were Penicillium janczewskii (10\%), P. implicatum (9\%), P. citrinum (8\%), P. lividum (7\%), P. minioluteum (7\%), P. oxalicum (7\%), P. simplicissimum (7\%), P. waksmanii (7\%) and P. citreonigrum (5\%). On the other hand, the dominant species during the rainy season in the Atlantic Forest soil were P. griseofulvum (16\%), P. aurantiogriseum (12\%), P. simplicissimum (12\%), P. janthinellum (11\%), P. fellutanum (9\%) and P. glabrum (9\%). In this biome, during the dry season, the dominant species were P. fellutanum (14\%), P. griseofulvum (13\%), P. glabrum (12\%), P. janthinellum (11\%) and P. restrictum (9\%) (Table 1).

In this study 14 species of Penicillium were exclusively found in the Caatinga biome (P. adametzii, P. citrinum, P. implicatum, P. janczewskii, P. lanosum, P. lapidosum, 


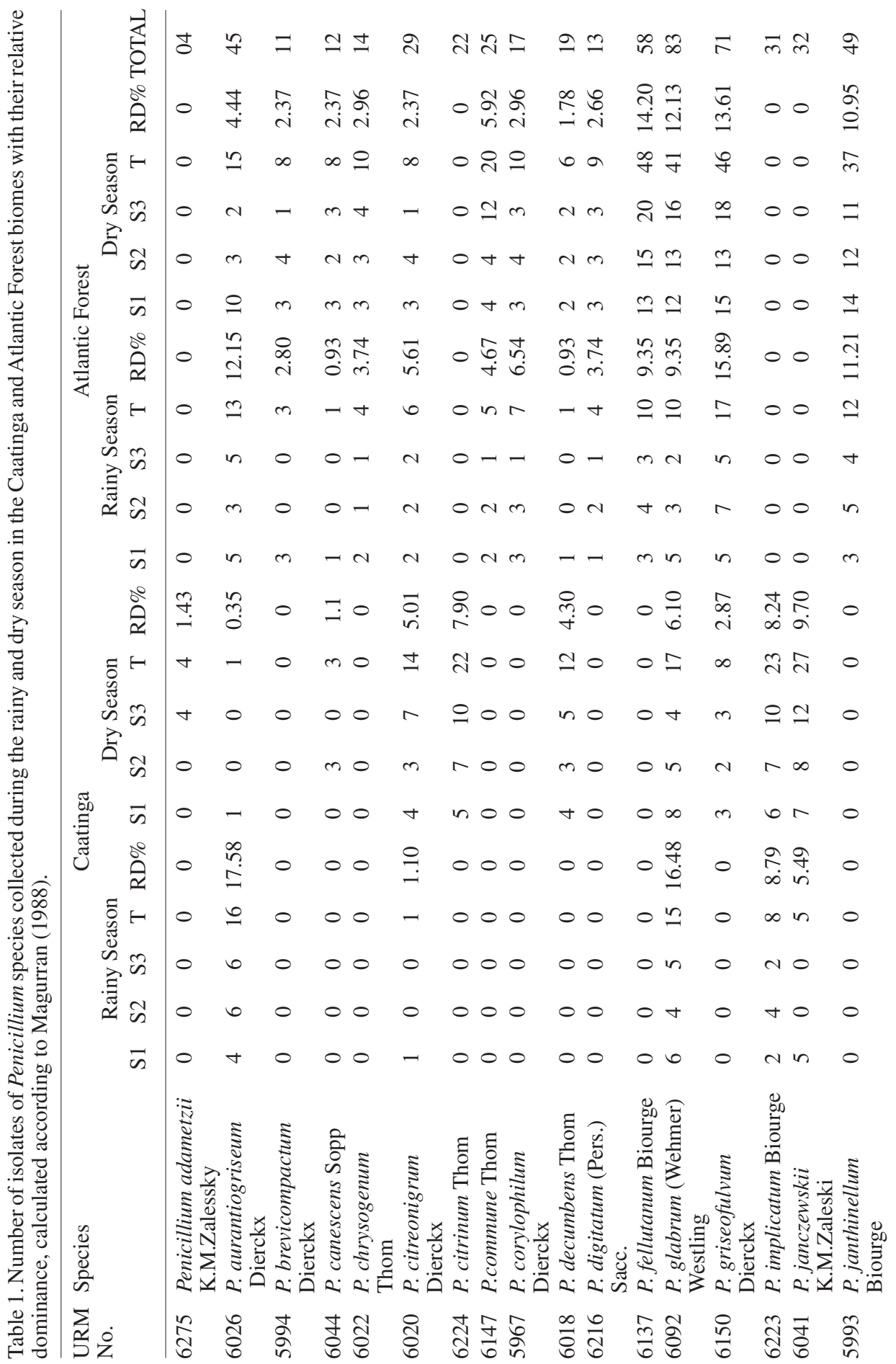




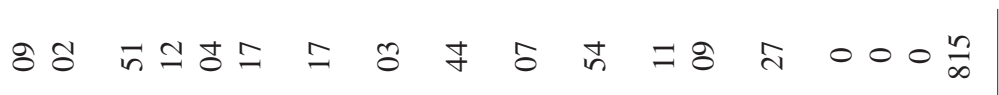

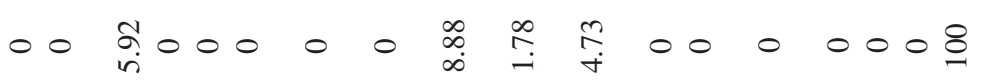

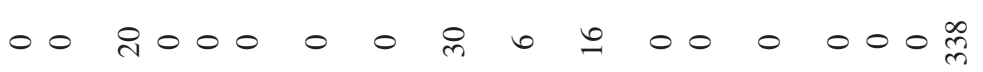

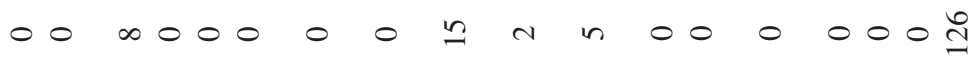
$00000000 I N$ in $000000 \underline{a}$ $00000000 \mathrm{~m} N$ N $000000 \underline{0}$

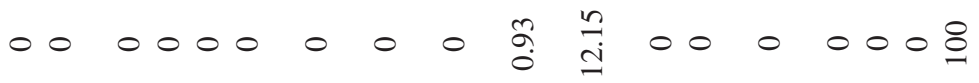
$000000000-M 0000000$ 0000000000 m $000000 \%$ $000000000-m 000000 m$

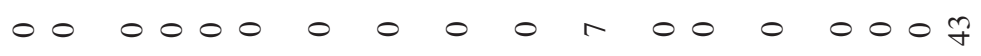

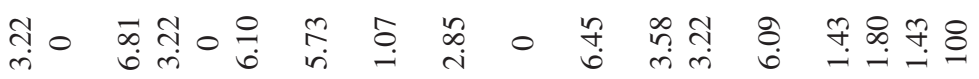

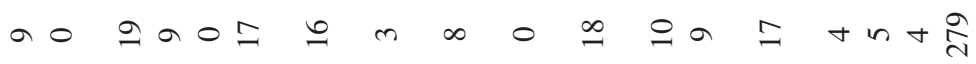
mo $a-00 m--0 a-m \infty-N d \tilde{b}$ mo $m \sin 0 \quad \infty-m \circ N m$ in $N N-\infty$ mormon $n-+0$ - $0 m+---\infty$ ○ तु

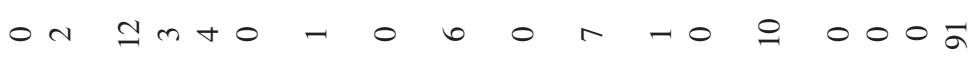

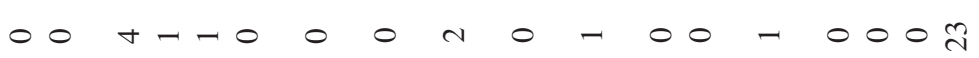

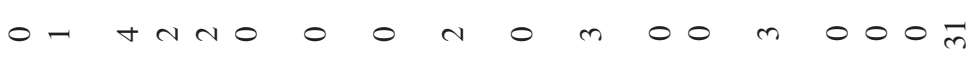

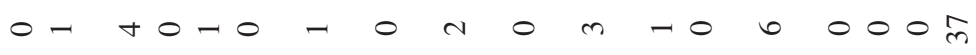

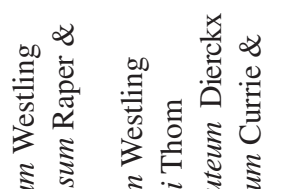

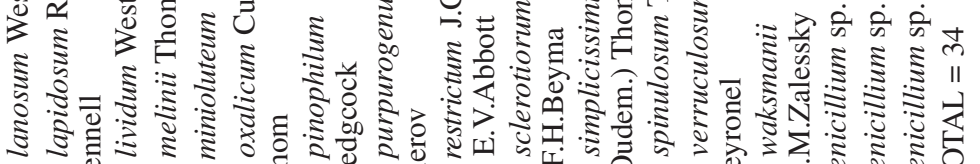

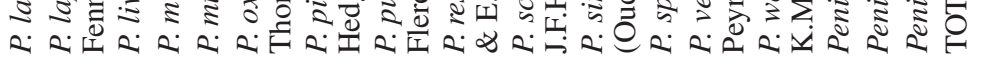

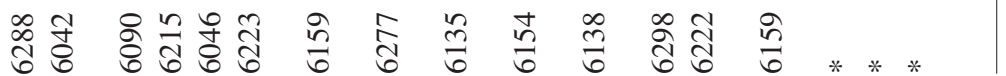




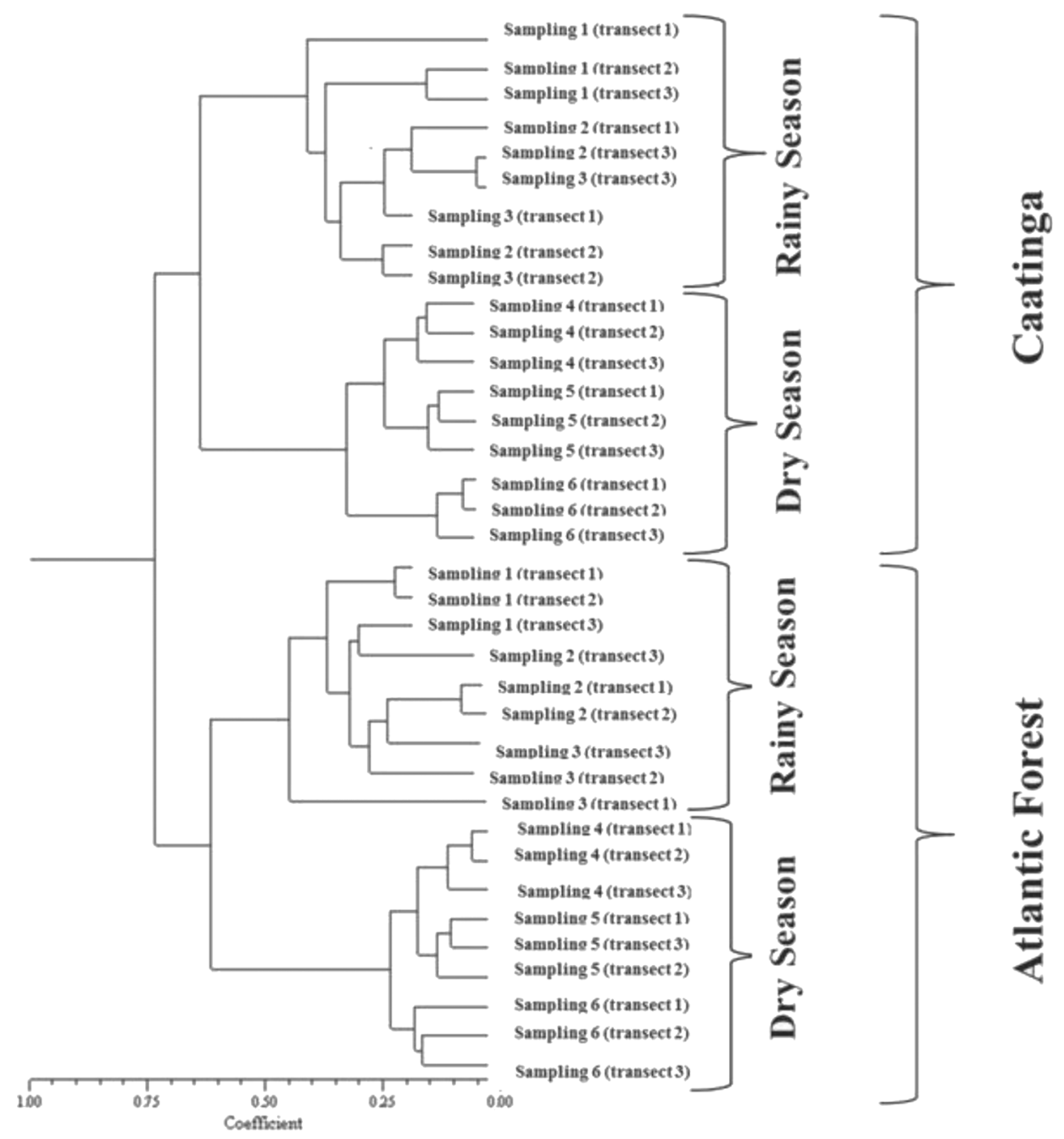

Fig. 1. Dendrogram of relatedness between fungal samples from the Caatinga and Atlantic Forest soils, collected during the rainy season in June, July and August 2009 and in the dry season during the months of February, March and April 2010. Statistical analysis based on Bray-Curtis index; WPGM connection method (weight proportional). Phenetic analysis: $r>0.8$.

P. melinii, P. minioluteum, P. oxalicum, P. pinophilum, P. purpurogenum, P. spinulosum, $P$. verruculosum and $P$. waksmanii). However, 8 species of Penicillium were exclusive found in the Atlantic Forest biome (P. brevicompactum, P. chrysogenum, $P$. commune, $P$. corylophilum, $P$. digitatum, $P$. fellutanum, $P$. janthinellum and $P$. sclerotiorum). 


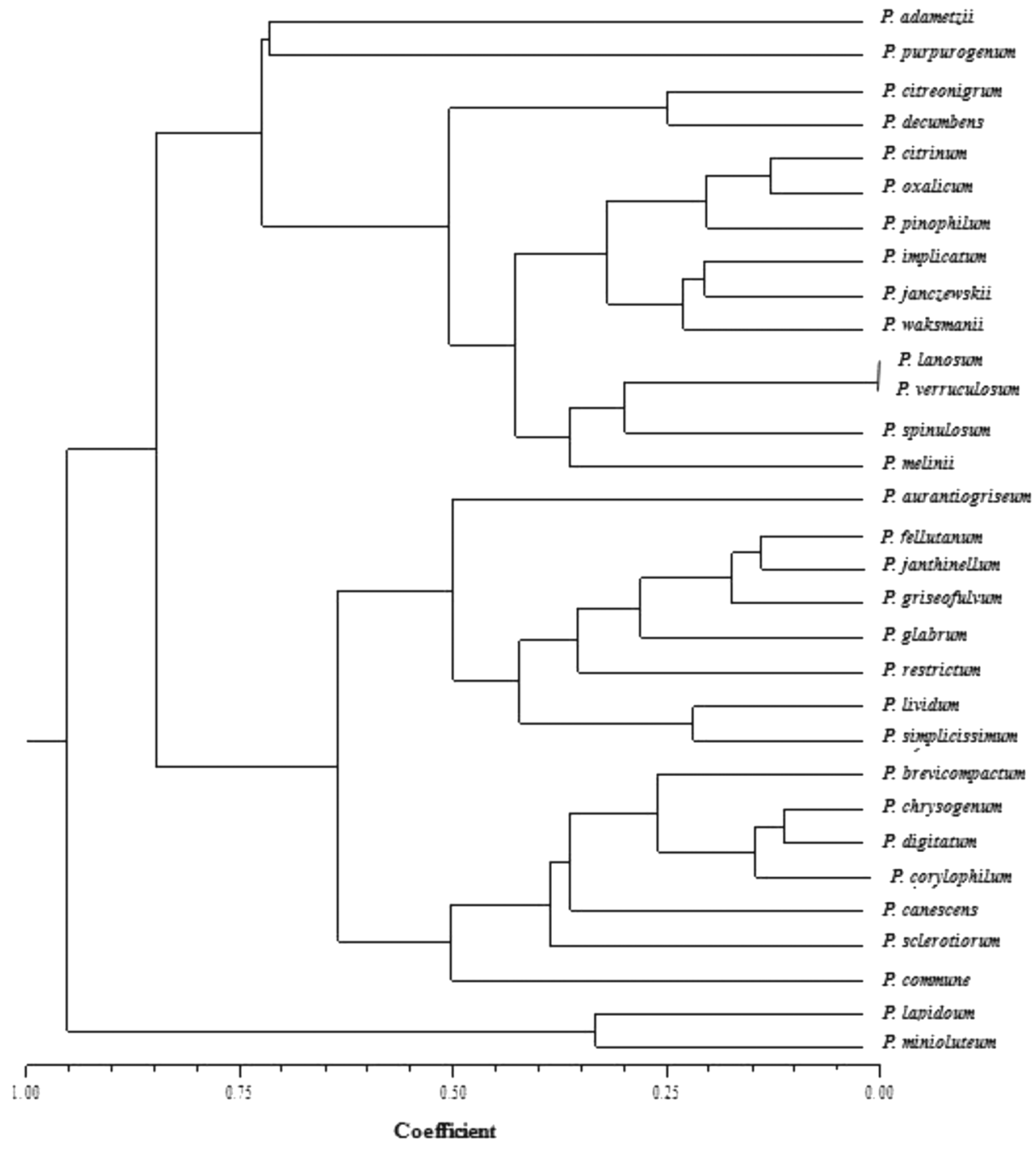

Fig. 2. Dendrogram of relatedness between species of Penicillium from the Caatinga and Atlantic Forest soils, according to the occurrence and number of isolates. Sample were collected during the rainy season in June, July and August 2009 and in the dry season during the months of February, March and April 2010. Statistical analysis based on Bray-Curtis index; connection method of proportional weight (WPGM, Weighted Pair-Group Method, Arithmetic Average). Phenetic analysis: r $>0.8$.

In addition, 8 species of Penicillium occurred in both biomes (P. aurantiogriseum, $P$. canescens, $P$. citreonigrum, $P$. decumbens, $P$. glabrum, $P$. griseofulvum, $P$. lividum, and $P$. simplicissimum) (Table 1). 


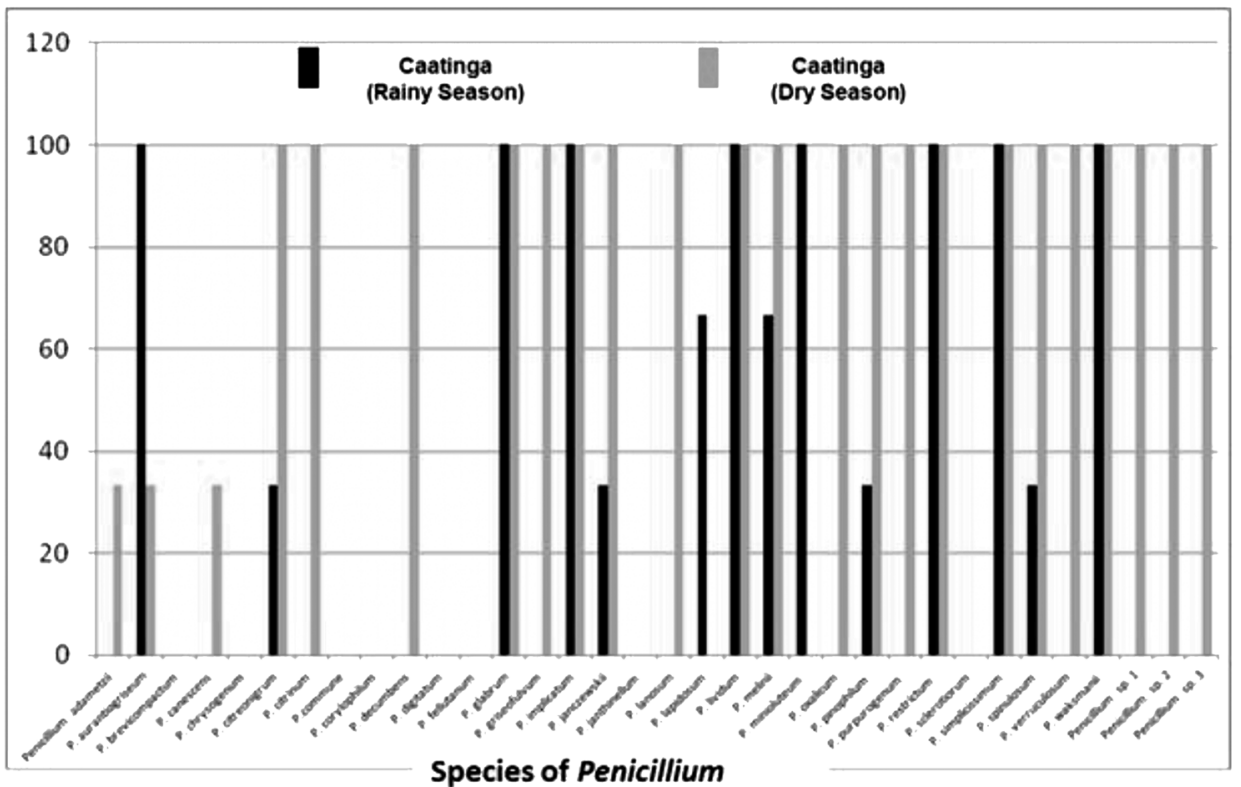

Fig. 3. Frequency (\%) of species of Penicillium in the rainy and dry seasons of the Caatinga biome.

\section{Discussion}

Penicillium is a cosmopolitan genus with few nutritional requirements of its species. They tolerate dry and hot as well as humid and cold environments (Pitt, 1991). Currently, this genus comprises 304 described species (Kirk et al., 2008). However, studies on communities of Penicillium present in soil in Brazil are scarce due to the lack of taxonomic experts in this genus. Furthermore, according to the Shannon's index for diversity (Shannon, 1948), soil samples from Caatinga and Atlantic Forest have a large diversity of species of Penicillium. In fact, in the present study the highest Shannon's index was achieved for the sampling 2 obtained from Caatinga soil. This sample was collected during the dry season and presented a rate of 4.10 bits.ind- ${ }^{1}$.

The Caatinga biome is characterised by a long drought period, which may explain the great diversity and richness of species of Penicillium in this ecosystem, especially during the dry season. It agrees with the theory of climate stability by Sanders (1968). According to this theory, due to a greater biological complacency more species will be present when environmental factors are stable. Indeed, Penicillium species are highly adaptable to different type of environments, including low water availability (Pitt, 1991). As described above, in this work these species were more diverse in the Caatinga biome than in the Atlantic Forest one. According to Raper \& Thom (1949), $P$. adametzii and P. lapidosum, isolated only in the Caatinga biome, are considered to be rare species. It indicates that this biome may harbour rare species that were not described yet for the science. 


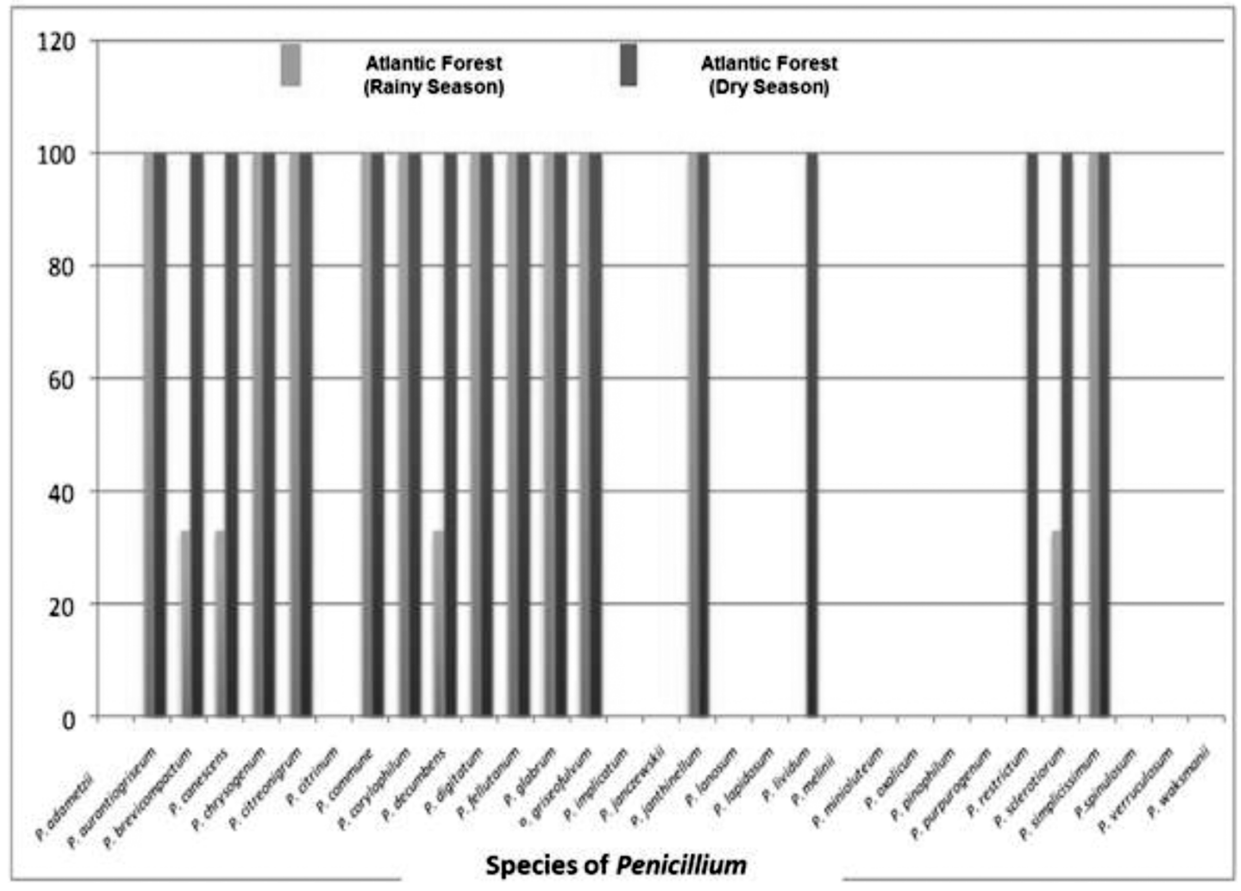

Fig. 4. Frequency $(\%)$ of species of Penicillium in the rainy and dry seasons of the Atlantic Forest biome.

Atlantic Forest soil has a high availability of nutrients in the topsoil at between 10 and $20 \mathrm{~cm}$ depth (Tabarelli et al., 2005). According to Begon et al. (1990), the increase of nutrient availability in a given environment does not increase the diversity of fungal species. However, it rather increases the number of individuals per species, which may explain the fact that the soil from the Atlantic Forest in this study is less rich in species of Penicillium, although the populations are larger.

Penicillium aurantiogriseum, $P$. glabrum, $P$. griseofulvum, $P$. lividum, $P$. restrictum and $P$. simplicissimum were the most abundant species in both biomes studied. However, P. implicatum and P. janczewskii occurred only in Caatinga soil, whereas $P$. fellutanum and $P$. janthinellum occurred only in the Atlantic Forest biome. These results corroborate with those data presented Domsch et al. (2007). According to these authors, $P$. implicatum and $P$. janczewskii are considered as cosmopolitan species distributed in different habitats from Alaska to Africa and South America. It justifies the presence of these species in the Caatinga soil. On the other hand, $P$. janthinellum is a common species in forest soil (Pitt, 1991). In contrast, $P$. fellutanum is considered to be a xerophilic species. Nevertheless, in the present study this fungal species was found only in the Atlantic Forest soil. At the ecological point of view, this species is closely similar to P. janthinellum, suggesting that they occupy similar ecological 


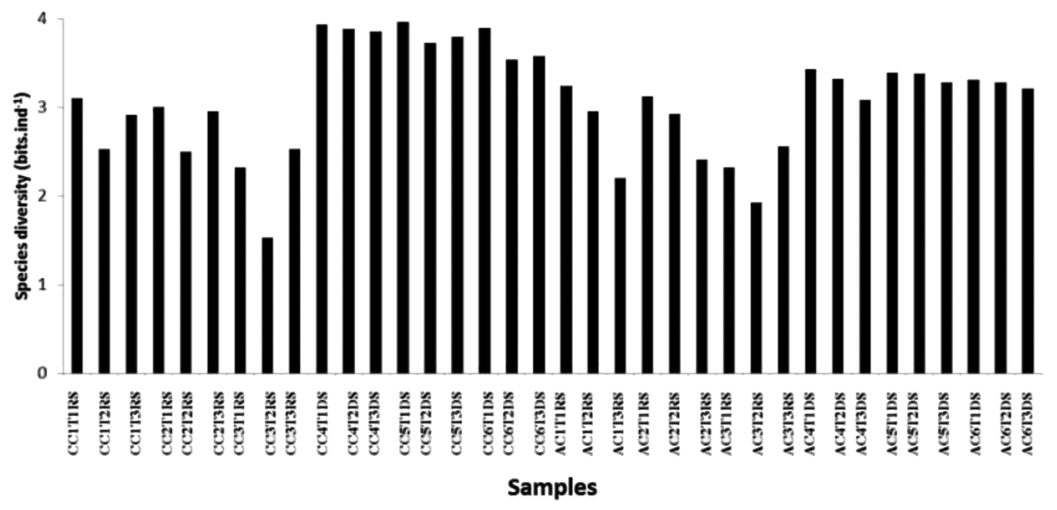

Fig. 5. Diversity (bits.ind ${ }^{-1}$ ) of Penicillium species in the Caatinga (C) and Atlantic Forest (A) in the rainy season (RS) and dry season (DS) in three transects (T1, T2, T3) and samples (C1, C2, C3). Statistical analysis based on Shannon index.

niches. Similar results were found for both $P$. implicatum and $P$. janczewskii species which are also ecologically similar species. Based on the data obtained in this study and according to Pielou's evenness index, the fungal populations from both studied areas are ecologically balanced.

The Bray-Curtis distance is an alternative to measure the similarity-dissimilarity between areas (Pinto-Coelho, 2002). Based on the geographical distance of both biomes, dissimilarity between the species found is observed through the formation of two major distinct groups of species of Penicillium; one group for each biome. Within each major group, the two subgroups formed were associated with the rainfall. In other words, the species differ between the rainy and dry seasons in both Caatinga and Atlantic Forest soils. This environmental factor appears to influence directly the ecological succession of species of Penicillium. It means that only the species that are physiologically adapted to the conditions of each environment remain viable and balanced in each period. This balance may be explained by the hypothesis of dynamic equilibrium proposed by Menge \& Sutherland (1987). According to these authors, those species that have no physiological competence to survive environmental changes, such as variations in rainfall, disappear for a time, until environmental conditions are conducive to their return. In the particular case of Penicillium, the spores in the soil may remain dormant until the favourable environmental conditions come up to their development.

Coutinho et al. (2010) isolated fungi from the rhizosphere of Cucumis melo (melon) grown in soil containing organic compounds in the semi-arid region of Petrolina, Pernambuco, Brazil. The authors found 25 genera and 75 species. Penicillium was the most representative genus, with 13 species $(P$. citrinum, $P$. corylophilum, $P$. decumbens, $P$. dierckxii, $P$. griseofulvum, $P$. janthinellum, $P$. pinophilum, $P$. restrictum, $P$. solitum, $P$. spinulosum, $P$. vinaceum and $P$. waksmanii). Their results were similar to those obtained in this work, in which $P$. citrinum, $P$. pinophilum, $P$. spinulosum and 
P. waksmanii were isolated only in soil from Caatinga. It indicates that these species are well adapted to the scarcity of water and nutrients and dominate communities in this ecosystem.

Recently, Fraga et al (2010) evaluated Trichocomaceae diversity in soils from two different Brazilian forest ecosystems. Over two years authors isolated 32 species of Penicillium, where $P$. decumbens was the most abundant. These results are corroborated by those obtained in the present study, where $P$. decumbens was only isolated from the Atlantic Forest soil and was common in all collections in both periods.

\section{Acknowledgments}

The authors thank to the Foundation for Science and Technology of the State of Pernambuco (FACEPE) for financial support, as well as Professors Dr. Maria José dos Santos Fernandes and Dr. Sigrid Newman (UFPE) and Researcher Dr. Francisco Rangel (CETENE) for all support during the fungal analyses and identification.

\section{References}

BARREIRO, E. \& V.S. BOLZANI 2009: Biodiversidade: fonte potencial para a descoberta de fármacos. - Quím. Nov. 32: 679-688.

BEGON, M., J.L. HARPER \& C.R. TOWNSEND 1990: Ecology: Individuals, Population and Communites. - Blackwell Sci Publ., Inglaterra.

CLARK, F.E., D.D. EVANS, J.L. WHITE, L.E. ENSMINGER, F.E. CLARK et al. 1965: Agar-plate method for total microbial count. -In Methods of soil analysis, Part 2. Chemical and microbiological properties. - Madson Inc. New York.

COLOMBO, A.F. \& C.A. JOLY 2010: Brazilian Atlantic Forest lato sensu: the most ancient Brazilian forest, and a biodiversity hotspot, is highly threatened by climate hange. - Braz. J. Biol. 70: 697-708.

COUTINHO, F.P., M.A.Q. CAVALCANTI \& A.M. YANO-MELO 2010: Filamentous fungi isolated from the rhizosphere of melon plants (Cucumis melo L. cv. Gold Mine) cultivated in soil with organic amendments. - Act. Bot. Bras. 24: 292-298.

DOMSCH, K.H., W. GAMS \& A. TRAUTE-HEIDI 2007: Compendium of soil fungi. $2^{\text {nd }}$ ed. - IHW, Eching.

DURIGAN, G., G.A.D.C. FRANCO, M. SAITO \&, J.B. BAITELLO 2000: Estrutura e diversidade do componente arbóreo da floresta na Estação Ecológica dos Caetetus, Gália, SP. - Rev. Bras. Bot. 23: 361-373.

FRAGA, M.E., M.G. PEREIRA, D.J. BARBOSA \& M.P. MELO 2010: Diversity of isolated Trichocomaceae from soil in two forest ecosystems. - Ci. Fl. 20: 167-175.

GOTO, B.T., L.C. MAIA, G.A. SILVA \& F. OEHL 2009. Racocetra intraornata, a new species in the Glomeromycetes with a unique spore wall structure. - Mycotaxon 109: 483-491.

HARRIS, D.M., I. WESTERLAKEN, Z.A. VAN DER KROG, A.K. GOMBERT, J. SUTHERLAND et al. 2009: Engineering of Penicillium chrysogenum for fermentative production of a novel carbamoylated cephem antibiotic precursor. - Metab. Eng. 11: 125-137.

HAWKSWORTH, D.L. 1991: The fungal dimension of biodiversity: magnitude, significance, and conservation. - Mycol. Res. 95: 641-655.

KENNEDY, A.C. \& K.L. SMITH 1995: Soil microbial diversity and the sustainability of agricultural soils. - Pl. Soil. 170: 75-86.

KIRK, P.M., F.P. CANNON, D.W. MINTER \& J.A. OLIVEIRA 2008: Dictionary of the Fungi. $10^{\text {th }}$ ed. - CAB Intern., Wallingford. 
KIRSOP, B.E. \& A. DOYLE 1991: Maintenance of Microorganisms and Cell Cultures - A Manual of Laboratory Methods. 2nd ed. - Acad. Press, London.

KOZAKIEWICZ, Z. 1989: Ornamentation types of conidia and conidiogenous structures in fasciculate Penicillium species using scanning electron microscopy. - Bot. J. Linn. Soc. 99: 273-293.

LEWINSONHN, T.M. \& P.I. PRADO 2002: Biodiversidade Brasileira - Síntese do Estado Atual do Conhecimento. $1^{\text {a }}$. ed. - Ed. Pinsky: São Paulo.

MAGURRAN, M.E. 1988: Ecological diversity and its measurement. - Univ. Press, Princeton.

MENGE, B.A. \& J.P. SUTHERLAND 1987: Community regulation: variation in disturbance, competition and predation in relation to environmental stress and recruitment. - Amer. Nat. 130: 730-757.

MENONCIN, S., N.M. DOMINGUES, D.M.G. FREIRE, G. TONIAZZO, R.L. CANSIAN et al. 2010: Study of the Extraction, Concentration, and Partial Characterization of Lipases Obtained from Penicillium verrucosum using Solid-State Fermentation of Soybean Bran. - Food. Bioproc. Technol. 3: 537-544.

MEYRS, N., R.A. MITTERMEIER, C.G. MITTERMEIER, G.A.B. FONSECA \& K. KENT 2000: Biodiversity hotspots for conservation priorities. - Nature 403: 853-845.

MORELATO, L.P.C. 2000: Introduction: The Brazilian Atlantic Forest. - Biotropica 32 (4b): 786-792.

O'BRIEN, H.E., J.L. PARRENT, J.A. JACKSON, J.M. MONCALVO \& R. VILGALYS 2005: Fungal Community Analysis by Large-Scale Sequencing of Environmental Samples. - Appl. Environ. Microbiol. 71: 5544-5550.

PINTO-COELHO, R.M. 2002: Fundamentos em Ecologia. - Artmed, São Paulo.

PITT, J.I. 1991: A laboratory Guide to Common Penicillium Species. - North Wales: Commonwealth Sci. Industrial Res. Org. - Div. Food Processing.

RAPER, K.B. \& C. THOM 1949: A manual of the Penicillia. - Baltimore, Williams and Wilkins.

RAPER, K.B. \& D.F. ALEXANDER 1945: Preservation of Molds by the Lyophil. - Proces. Micol. 37: 499-525.

RODAL, M.J.N., F.R. MARTINS \& E.V.S.B. SAMPAIO 2008: Levantamento quantitativo das plantas lenhosas em trechos de vegetação de Caatinga em Pernambuco. - Rev. Caat. 21: 192-205.

ROHLF, F.J. \& D.L. FISHER 1968: Test for hierarchical structure in random data sets. - Syst. Zool. 17: 407-412.

SAMSON, R.A. \& J.C. FRISVAD 2004: Penicillium Subgenus Penicillium: new Taxonomics Schemes, Mycotoxins and Other Extrolites. - Stud. Mycol. 49: 1-260.

SANDERS, H.L. 1968: Marine benthic diversity: a comparative study. - Amer. Nat. 102: 243-282.

SHANNON, C.E. 1948: A mathematical theory of communication. - Bell. Syst. Tech. J. 27: 379-423

SOCCOL, C.R., L.P.S. VANDENBERGHE, C. RODRIGUES \& A. PANDEY 2006: New Perspectives for Citric Acid Production and Application. - Food Technol. Biotechnol. 44: 141-149.

TABARELLI, M., L.P. PINTO, J.M.C. SILVA, M.M. HIROTA \& L.C. BÊDE 2005: Desafios e oportunidades para a conservação da biodiversidade na Mata Atlântica brasileira. - Megad. 1: 132-138.

Manuscript submitted February 22, 2012; accepted September 6, 2012. 